\title{
Vyhledávání mimořádných prožitků a preference učebního stylu studenta
}

\author{
Dita Culková \\ Univerzita Hradec Králové, Pedagogická fakulta, Katedra tělesné výchovy a sportu
}

Redakci zasláno 25. 2. 2013 / upravená verze obdržena 27. 5. 2013 / k uveřejnění přijato 28. 5.2013

\begin{abstract}
Abstrakt: Cílem empirické studie je zjistit, jaké učební styly studenti preferují v souvislosti s tendencí vyhledávat mimořádné prožitky a jaké tvoří přirozené skupiny (shluky) z hlediska těchto dvou proměnných, pohlaví a příslušnosti ke všeobecně či tělovýchovně zaměřené gymnaziální třídě. V první části jsou představena teoretická východiska, kterými jsou teorie stylu učení autorky Dunnové a koncept tendence vyhledávat mimořádné prožitky autora Zuckermana. Druhá část př́íspěvku popisuje použité výzkumné metody včetně ověření reliability a validity použitého nástroje pro sběr dat, kterým je dotazník. Metodou zpracování dat je shluková analýza, která zprostředkovává vhled do velkého počtu proměnných. Třetí část studie seznamuje s hlavními výsledky, které diskutuje a zpracovává do doporučení do praxe. Nejvýraznější rozdíly mezi pohlavími a příslušností k typu třídy byly zjištěny $\mathrm{v}$ tendenci vyhledávat mimořádné prožitky a částečně ve stylech učení. Dívky sportovních tříd nejméně vyhledávají napětí a dobrodružství, nevyhledávají nové zkušenosti, jsou nejvíce rezistentní vůči nudě a nejvíce respektují normy a pravidla. Chlapci jsou nejčastěji členy shluku, který je charakteristický nevyhledáváním napětí a dobrodružství, vyhledáváním nových zkušeností, prožitků prostřednictvím nerespektování norem a nízkou rezistencí vůči nudě. Chlapci ze sportovně zaměřených tříd mají nízkou odpovědnost při učení, úkoly potřebují mít strukturované a preferují zážitkové učení. Z uvedeného vyplývá, že preference učebního stylu a tendence vyhledávat mimořádné prožitky může u gymnaziálních studentů souviset, stejně tak může souviset s pohlavím a příslušností k typu třídy.
\end{abstract}

Klíčová slova: styl učení, kognitivní styl, mimořádné prožitky, tendence vyhledávat mimořádné prožitky, Dotazník stylu učení, zájmů a zálib, gymnázia s rozšířenou tělesnou výchovou a sportovní přípravou

\section{Formulace problému}

Cílem empirické studie je zjistit, jaké učební styly studenti preferují v souvislosti $s$ tendencí vyhledávat mimořádné prožitky. Jde o dvě proměnné, $\mathrm{s}$ jejichž vzájemnou souvislostí jsem se doposud v odborné literatuře nese- 
tkala. Bližší analýza vzájemného vztahu obou proměnných a přiblížení možných souvislostí jsou hlavním př́nosem studie. Východisky jsou koncepce Zuckermana (1978) z oblasti vyhledávání mimořádných prožitků a Dunnové (Dunn \& Dunn, 1978) z oblasti učebních stylů.

Z hlediska stylů učení se studie věnuje především průběhu učení. Stylem učení je rozuměn specifický postup svébytný svou orientovaností, motivovaností, strukturou, posloupností, hloubkou, propracovaností a flexibilitou. Vyvíjí se z vrozeného základu, ale proměňuje se i během života (Mareš, 1998, s. 75). Dalším základním pojmem této práce je „vyhledávání mimořádných prožitků“. Mimořádný prožitek (sensation) je rozuměn jako nový, silný, výjimečný a je používán v kontextu „tendence vyhledávat mimořádné prožitky“ (sensation seeking tendency). Tato tendence je determinována jak geneticky, tak vnějšími faktory (Zuckerman, 1994, s. 25), souvisí s podstupováním rizika (Zuckerman, 2000, s. 52) a je součástí žákovy osobnosti. Studentem preferovaný učební styl, který se v průběhu života vyvíjí z vrozeného základu, může souviset $\mathrm{s}$ mnoha okolnostmi, mírou tendence vyhledávat mimořádné prožitky nevyjímaje. Pragmatická koncepce učebních stylů Dunnové (2000) mezi subškály Dotazníku stylu učení řadí mimo jiné i zážitkové učení, které je charakterizováno prožitkem, pohybem, praktickou zkušeností a autentičností. Tyto atributy jsou vlastní i vyhledávání mimořádných prožitků.

Výzkumy, které se explicitně týkají vyhledávání prožitků a vzdělávání (Farley, 1981; Wentzel, 1993; Carter \& Stewin, 1999; Blum, Beuhring, \& Rinehart, 2000; Ang \& Woo, 2003), naznačují, že žáci s vysokou tendencí vyhledávat mimořádné prožitky mají negativnější přístup ke školní docházce a více inklinují k hyperaktivitě a kriminalitě než žáci s nízkou tendencí. Je indikována vazba mezi vyhledáváním mimořádných prožitků, nedostatečnými studijními dovednostmi a obecnou nespokojeností s učiteli, školou a učebním procesem. Autoři upozorňují na roli nepodnětných vzdělávacích metod tlumících intelektuální zvídavost studentů, kteří vyhledávají mimořádné prožitky, a zvyšujících pravděpodobnost kriminálního chování jako důsledek. Rybenský (2008), Krásová a Rost (2008) a Kuban (2001) ve svých pracích docházejí k závěrům, že vyznavači specifického životního stylu, konkrétně mladí lidé provozující některé druhy sportů, vykazují nadprůměrnou tendenci vyhledávat mimořádné prožitky. I z tohoto důvodu byla tato studie realizována mezi studenty gymnázií s rozšířenou tělesnou výchovou a sportovní př́ípravou. Již spekulací je koncentrace jedincủ s vyšší tendencí vyhledávat mimořádné prožitky přímo ve sportovně zaměřených gymnaziálních třídách. Př́ípadné 
potvrzení této spekulace by ovšem mohlo přispět ke zkvalitnění vyučovacího procesu u těchto skupin. Sledovány byly také rozdíly mezi pohlavími. Jak Kuban (2006), tak Mareš a Slavík (2004) v rámci standardizace české verze dotazníku, který pro tuto studii využívám, rozdíly mezi pohlavími objevují, tedy rozdíly bylo možné očekávat.

Konkrétním cílem studie je zjistit, jaké učební styly studenti preferují v souvislosti s různou mírou tendence vyhledávat mimořádné prožitky. Obecným cílem je snaha přispět do diskuze o výukovém procesu, především do diskuze o kompatibilitě učebních stylů a vyučovacích metod.

\section{Přehled relevantní literatury}

\subsection{Vyhledávání mimořádných prožitků}

Pojem prožitek je v tomto př́íspěvku rozuměn jako prožitek mimořádný, jinak řečeno prožitek nový, silný a výjimečný, který jako první používá Zuckerman (1978), a to ve spojení tendence vyhledávat mimořádné prožitky (sensation seeking tendency; překlad Kuban, 2006). Zuckerman tuto tendenci označuje jako danou genetickými i vnějšími faktory (Zuckerman, 1994, s. 19) a jako související s podstupováním rizika (Zuckerman, 2009, s. 456), které může být dle Kubana (2006) fyzické, sociální i finanční.

Někteří autoři nachází statisticky významný vztah mezi mírou tendence vyhledávat mimořádné prožitky a tendencí odhalovat osobní city a pocity, averzí ke strukturovaným a formálním situacím, dobrodružným cestováním, vyhýbáním se opakovaným dějům, náklonností k intenzivním zážitkům, náchylností k pocitům nudy a tendencí ke ztrátě zábran (Galloway \& Lopez, 1999). Vysoká tendence vyhledávat mimořádné prožitky je dle některých autorů předpokladem pro zneužívání návykových látek (Jaffe \& Archer, 1987), pro opakované sexuální zkušenosti a pro nebezpečné sporty (Zuckerman, 1979). Negativní korelace byly zjištěny u konservatismu (Glasgow, Cartier, \& Wilson, 1985), hypochondrie a tendencí k depresím (Montag \& Birenbaum, 1986; Watson \& Jacobs, 1977). Uvedené projevy mohou mít v důsledku vliv na výchovně-vzdělávací proces i na způsoby žákova či studentova učení. Bližší souvislost s procesem učení je uvedena v podkapitole 2.3.

Projevy zajištujuící potřebnou saturaci mimořádnými prožitky, jejíž míra je individuální, mohou být projevy s negativními vlivy na samotného jedince, jeho okolí nebo procesy, ve kterých se nachází, nebo může jít o projevy 
pozitivní a prospěšné. V České republice se tendenci vyhledávat mimořádné prožitky věnuje Hošek (1997) a Kuban (2006), ovšem téměř nikdo na tuto problematiku nenahlíží z hlediska pedagogického, kdy je s tendencí žáka či studenta vyhledávat mimořádné prožitky pracováno jako $\mathrm{s}$ faktorem ovlivňujícím výchovně-vzdělávací proces. Tato studie pedagogický pohled na vyhledávání mimořádných prožitků nabízí.

\subsection{Učební styly}

Pojmy učení a učební a kognitivní styl jsou v kontextu tohoto příspěvku rozuměny v souladu s pojetím Mareše (1998). Učení je viděno z hlediska procesuálně-kognitivního a je chápáno jako děj, v jehož průběhu člověk zažívá řadu změn, ke kterým dochází především na základě zkušenosti, která se následně transformuje na vědění. Kognitivní styl je pak chápán jako způsob poznávání, vnímání, tř́iění a ukládání podnětů, je prostředkem učení, ovlivňuje jeho kvalitu a může se učením zdokonalovat. Stylem učení jsou rozuměny preferované postupy, které se během života proměňují a jejichž identifikace může být užitečná pro cílené zásahy do procesu učení.

Mezi řadou koncepcí učebních stylů vystupuje koncepce Dunnové (2000), jejíž pohled je velmi pragmatický a která se snaží styly učení vztáhnout k 21 proměnným. Styly učení vymezuje jako biologicky a vývojově podmíněné a upozorňuje na užitečnost objevení studentových silných a slabých stránek při učení. Tyto stránky vztahuje k proměnným, které dělí do čtyř skupin: vlivy prostředí, emocionalita, sociální potřeby a fyzické potřeby. Koncepce Dunnové je $\mathrm{z}$ hlediska učebních stylů v této studii výchozí. Je využit Dotazník stylu učení, jehož autorkou je Dunnová.

\subsection{Vyhledávání mimořádných prožitků a preference učebního stylu studenta}

Při hledání výzkumů týkajících se preferencí učebních stylů v souvislosti $\mathrm{s}$ vyhledáváním mimořádných prožitků nenacházím žádné dostupné výsledky př́mo k této problematice. Nacházím však výstupy související. Ang a Woo (2003) uvádí, že chlapci s vysokou tendencí vyhledávat mimořádné prožitky mají negativnější přístup ke školní docházce a více inklinují k hyperaktivitě a kriminalitě než chlapci s nízkou tendencí. Carter a Stewin (1999) indikují vazbu mezi vyhledáváním mimořádných prožitků, nedostatečnými studijními dovednostmi, asociálním a nekonformním chováním a obecnou nespokojeností s učiteli, školou a učebním procesem. Farley (1981) upozorňuje 
na roli nepodnětných vzdělávacích metod tlumících intelektuální zvídavost studentů, kteří vyhledávají mimořádné prožitky a zvyšujících tak pravděpodobnost kriminálního chování jako důsledek. Blum et al. (2000) upozorňují na to, že těžkopádná vyučovací rutina by mohla vést $\mathrm{k}$ silnému pocitu nudy u těch, kteří mají vyšší tendenci vyhledávat mimořádné prožitky a kteří s větší pravděpodobností neudrží pozornost, z čehož mohou plynout problémy jako neklid, upovídanost a vyrušování. Studie se shodují, že pozitivní intelektuální výsledky jsou závislé na správném vyučování, které zohledňuje individuální potřeby žáka (Wentzel, 1993), a že je vhodné aplikovat kompatibilní výukové metody k preferovaným učebním stylům žáků (Lovelace, 2005).

Otázka, kterou si v tomto příspěvku kladu, je, zda míra tendence vyhledávat mimořádné prožitky souvisí s preferovaným učebním stylem studenta a je-li $\mathrm{v}$ těchto dvou proměnných rozdíl mezi studenty a studentkami sportovně a všeobecně zaměřených tříd na českých gymnáziích. Míra tendence vyhledávat mimořádné prožitky je do velké míry vrozená, stejně tak učební styl je částečně biologicky podmíněn. Momentem, kde se obě proměnné prolínají nejtěsněji, je potřeba prožívání při učení. Použitý dotazník učebních stylů obsahuje subškálu zážitkové učení, která potřebu prožívání při učení zjištuje. Stejně jako tendence vyhledávat mimořádné prožitky je zážitkové učení založené na autentickém prožitku. Tedy v tomto místě je očekávána souvislost nejvíce.

\section{Cíl práce}

Cílem práce je zjistit, jaké učební styly studenti preferují v souvislosti s různou mírou tendence vyhledávat mimořádné prožitky a jaké tvoří přirozené skupiny (shluky) z hlediska těchto dvou proměnných, př́islušnosti k typu třídy a pohlaví.

\section{Použité výzkumné metody a postupy}

\subsection{Výzkumný soubor}

Výzkumným souborem byla skupina gymnaziálních studentů, a to ze všeobecných tříd a tříd s rozšiřenou tělesnou výchovou a sportovní prŕípravou. Výzkumný soubor byl vybrán náhodným stratifikovaným výběrem z gymnázií České republiky, která nabízejí studijní programy s rozšířenou sportovní př́pravou nebo tělesnou výchovou. Některé z vybraných škol nabízejí všeo- 
becný i tělovýchovný vzdělávací program, některé pouze tělovýchovně zaměřený. Základní soubor škol byl získán v Ústavu pro informace ve vzdělávání k 1. 5. 2010 a tvořilo ho 16 škol. Náhodným výběrem bylo zvoleno $10 \mathrm{z}$ nich. $\mathrm{V}$ těchto školách bylo osloveno vedení a třídní učitelé tř̌etích ročníků čtyřletých, respektive sedmých ročníků osmiletých gymnázií. $V$ těchto tř́dách byly dotazníky vyplněny. Dvě z oslovených škol si šetření nepřály a data z jedné školy nebyla z technických důvodů doručena ke zpracování. Konečný počet dotazníků, které byly vyplněny a zpracovány, je 300. Jedná se o respondenty ze sedmi různých škol, ze sedmnácti různých tříd, z toho 142 studentů bylo ze všeobecně zaměřených tříd a 158 studentů ze tř́́d s rozšířenou sportovní př́ípravou nebo tělesnou výchovou. Celkem dotazník vyplnilo 148 děvčat a 147 chlapců. Ze všeobecně zaměřených tř́íd bylo administrováno 76 děvčat a 61 chlapců, z tělovýchovně zaměřených tříd 72 děvčat a 86 chlapců. 5 dotazníků bylo z důvodu chybného vyplnění vyřazeno (nebyly zodpovězeny všechny otázky).

Pro ověření reliability dotazníku bylo na vybraném gymnáziu po dohodě s vedením školy administrováno dalších 55 dotazníků. Opakované měření proběhlo u 36 studentů z uvedených 55 , a to po dvou měsících od prvního měření.

\subsection{Metoda získání a vyhodnocení empirických dat}

Pro sběr dat byl použit výzkumný nástroj Dotazník stylů učení, zájmů a zálib, který byl sestaven ze dvou standardizovaných dotazníků. Jeho první část tvoří Dotazník stylu učení (Mareš \& Slavík, 2004) a jeho druhou část Test zájmů a zálib (Kuban, 2006). Test zájmů a zálib byl zařazen v kompletní podobě, z Dotazníku stylu učení byly použity pouze položky podchycující vybrané proměnné. Hlavním důvodem eliminace některých položek v Dotazníku stylu učení bylo zkrácení časové náročnosti dotazníku a zamezení snížení kvality odpovědí $\mathrm{v}$ jeho druhé polovině. Dalším důvodem bylo nepoužití proměnných, které věcně nesouvisí s hlavním záměrem výzkumu, jehož dílčí část prezentuji, což zvyšuje validitu výsledků. Reliabilita není tímto postupem snížena, jelikož její výpočet vychází ze souborů otázek (proměnných), nikoliv z celku dotazníku. Zachované soubory proměnných nebyly eliminací některých položek narušeny. Potvrzení reliability je zajištěno provedenou faktorovou analýzou, díky které lze určit, seskupují-li se otázky podle předpokladů, tedy podle subškál dotazníku. Podrobněji se $\mathrm{k}$ faktorové analýze této části dotazníku vyjadřuji v podkapitole 4.3. 


\subsubsection{Dotazník stylu učení, zájmů a zálib}

Dotazník stylů učení, zájmů a zálib byl sestaven z kompletní podoby Testu zájmů a zálib a nekompletního Dotazníku stylu učení LSI (Learning style inventory). Z Dotazníku stylu učení bylo z 21 proměnných použito $8 \mathrm{z}$ nich: vnitřní motivace, vytrvalost, odpovědnost, strukturování úkolů, zážitkové učení, ranní/večerní učení, dopolední učení a vnější motivace-učitel. Protože byl výzkum zaměřen na hledání souvislosti mezi preferencemi při učení a tendencí vyhledávat mimořádné prožitky, soustředili jsme se u dotazníku LSI na výběr proměnných, které souvisí s osobností respondenta ve smyslu vrozených či získaných osobnostních struktur, méně již s ryze naučenými návyky.

\section{Dotazník stylů učení}

V roce 1967 vytvořili Dunnová a Dunn (1978) nástroj nazývaný Dotazník stylu učení LSQ (The Learning Style Questionnaire), jehož česká verze vznikla ze tří na sobě nezávislých překladů Pýchové, Kantorové a Mareše v roce 1992 (Mareš \& Skalská, 1994), a byly vytvořeny normy pro základní školy. Dotazník je určen studentům základních a středních škol a zjišt’uje, co jednotliví žáci preferují při studiu, za jakých podmínek se nejlépe soustředí, čemu dávají přednost, když se učí nové nebo obtížné učivo, když se mají naučit novým dovednostem. Charakterizuje jejich styly učení (Mareš \& Slavík, 2004). Formátem odpovědí v dotazníku je škála 1 až 5 , kde 1 znamená nesouhlasím, 2 spíš nesouhlasím, 3 těžko rozhodnout, 4 spíš souhlasím a 5 souhlasím.

\section{Test zájmů a zálib}

Druhou polovinu Dotazníku stylů učení, zájmů a zálib tvoří Test zájmů a zálib, jehož standardizaci v české verzi provedl v roce 2003 Kuban (2006) a jehož originální verzi vypracoval v roce 1978 Zuckerman ve znění Sensation Seeking Scale form $V$ (dále jen SSS-V). SSS-V se skládá ze čtyřiceti položek rozdělených do čtyř subškál, vždy o deseti položkách v jedné subškále. První subškála je Vyhledávání napětí a dobrodružství (TAS - Thrill and Adventure Seeking), kde jde o oblast sportu a fyzické činnosti. Druhou subškálou je Vyhledávání zkušeností (ES - Experience Seeking), oblast smyslového vnímání. Třetí subškálou je Disinhibice (Dis - Disinhibition), oblast respektování sociálních a morálních norem, a čtvrtou je Vnímavost nudy (BS - Boredom Susceptibility), oblast resistence vůči opakovaným podnětům. Celkový dosažený skór 
vyjadřuje tendenci testovaného vyhledávat nové a silné prožitky, přizpůsobovat se novým věcem i novým životním situacím či změně životního stylu (Kuban, 2006). Formátem odpovědí v dotazníku byl nucený výběr ze dvou odpovědí, které se svou podstatou vylučují.

Data z dotazníků byla přepsána do programu Microsoft Excel a výsledky byly zpracovány pomocí popisných charakteristik (průměr, směrodatná odchylka, modus, medián, variační rozpětí). Vzhledem k velkému množství proměnných, mezi kterými nejsou známy vztahy, byla pro zjištění přirozených skupin použita shluková analýza typu K-průměrů.

\subsection{Stabilita, vnitřní konzistence a validita Dotazníku stylu učení, zájmů a zálib}

Reliabilita neboli spolehlivost výzkumného nástroje udává, že je nástroj spolehlivý, když rozptyl jeho chyb je malý. Pro zajištění reliability a validity použitého dotazníku byly aplikovány stejné metody, jaké použili autoři obou samostatných dotazníků. Reliabilita byla zajištěna pomocí korelačních koeficientů mezi opakovanými měřeními a Cronbachovo alfa. Pro zajištění validity byl pro část dotazníku Test zájmů a zálib vypočítán korelační koeficient mezi výsledkem dosaženým $v$ testu a zvoleným kritériem, kterým byla tří- a sedmistupňová škála. Pro část Dotazníku stylu učení byla provedena faktorová analýza.

\section{Stabilita}

Pro ověření stability dotazníku, tedy vlastnosti, která určuje míru stálosti dotazníku při jeho opakovaném použití, byly vypočítány korelační koeficienty mezi prvním a druhým měřením. Opakované měření bylo uskutečněno se studenty třetích ročníků čtyřletého gymnázia jednoho z libereckých gymnázií a měření se zúčastnilo 36 respondentů. Korelační koeficienty mezi opakovanými měřeními pro zjištění stability byly pro jednotlivé subškály a škálu SSS-V následující: TAS - 0,647, ES - 0,711, Dis - 0,589, BS - 0,455, SSS-V - 0,623. Aritmetický průměr korelací subškál (Pearsonův korelační koeficient) při opakovaném měření je 0,601 . Kritické hodnoty pro subškály SSS-V pro $n=36$ jsou 0,329 na hladině významnosti 0,05 a 0,424 na hladině významnosti 0,01 .

Korelační koeficienty jednotlivých subškál LSI části dotazníku mezi prvním a druhým měřením jsou: vnitřní motivace (vm) 0,541, vytrvalost při učení 
(v) 0,392, odpovědnost (o) 0,524, potřeba strukturování úkolů (su) 0,544, preference zážitkového učení (zu) 0,712, preference ranního versus večerního učení (rv_u) 0,711, preference dopoledního učení (du) 0,541, vnější motivace - učitel (vm_u) 0,621. Aritmetický průměr korelačních koeficientů mezi prvním a druhým měřením všech osmi subškál je 0,573. Kromě subškály LSI vytrvalost při učení (v), která má nižší hodnotu, jsou v obou částech dotazníku korelační koeficienty dostatečně vysoké, abychom mohli dotazník považovat za stabilní.

\section{Vnitřní konzistence (Cronbachovo $\alpha$ )}

Cronbachovo $\alpha$ vyjadřuje, jaká část získaného rozptylu připadá na skutečné rozdíly mezi měřenými probandy a jaký je podíl chybových, respektive náhodných složek. Vychází z předpokladu, že by všechny položky měřící jednu vlastnost měly mít mezi sebou kladné a dostatečně vysoké korelace. Aritmetický průměr korelačních koeficientů mezi výsledky jednotlivých subškál části dotazníku SSS-V je 0,302 a normované Cronbachovo $\alpha$ je 0,633. U části dotazníku LSI je průměr korelací mezi jednotlivými subškálami 0,141 a normované Cronbachovo $\alpha$ je 0,57 . U obou částí dotazníku výsledky indikují, že vnitřní konzistence mezi jednotlivými subškálami je značná, u části SSS-V je velmi podobná hodnotám, které uvádí Kuban (2006), u části LSI je hodnota nižší, ovšem stále dostačující.

\section{Validita}

Jako míru validity české verze Testu zájmu a zálib Kuban (2006) použil korelační koeficient mezi výsledkem dosaženým v testu a zvoleným kritériem, kterým byla tří- a sedmistupňová škála rizikovosti sportů. Původní třístupňová škála (Breivik, 1999) byla autorem české verze Kubanem (2006) rozšířena na sedmistupňovou. Důvodem byla velká stručnost původní třístupňové škály, kterou Kuban (2006, s. 78) považoval za nedostatečnou. Na základě hlavních hledisek původní škály vytvořil škálu o více stupních. Korelační koeficient mezi původní třístupňovou škálou a nově vytvořenou sedmistupňovou škálou je 0,774. Zjištěná hodnota korelačního koeficientu mezi SSS-V a sedmistupňovou škálou je 0,578 a mezi SSS-V a tř́stupňovou škálou je 0,506. $\mathrm{V}$ obou př́padech test významnosti vypočítaného korelačního koeficientu na hladině významnosti $\alpha=0,05$ zamítá nulovou hypotézu, tedy lze učinit závěr, že škála SSS-V je dostatečně validní k testování tendence k vyhledávání mimořádných prožitků. 
Vzhledem k dostupným výsledkům faktorové analýzy u středoškolské populace u části dotazníku LSI, byla pro ověření validity provedena faktorová analýza i u použitého nově vytvořeného dotazníku LSI. Bylo vygenerováno 8 faktorů, z toho 6 faktorů odpovídalo šesti subškálám dotazníku, a to subškálám Odpovědnost, Ranní-večerní učení, Zážitkové učení, Strukturování úkolù, Vnitřní motivace-učitel a Dopolední učení. Jedna ze dvou otázek subškály Vytrvalost korelovala se subškálou Odpovědnost, druhá korelovala se subškálou Vnitřní motivace. Vnitřní motivace byla rozdělena na dva faktory. Sumou druhých mocnin faktorových zátěží pro jednotlivé manifestní proměnné jsme získali hodnoty odpovídajících komunalit, přičemž celková komunalita pro dotazník je 0,668 . Tedy faktorová analýza vysvětluje $66,8 \%$ rozptylu dat.

\section{$5 \quad$ Výsledky a jejich interpretace}

Shluková analýza byla provedena zvlášt' pro část dotazníku SSS-V a zvlášt' pro LSI a následně byly sledovány počty společných respondentů z obou částí dotazníku.

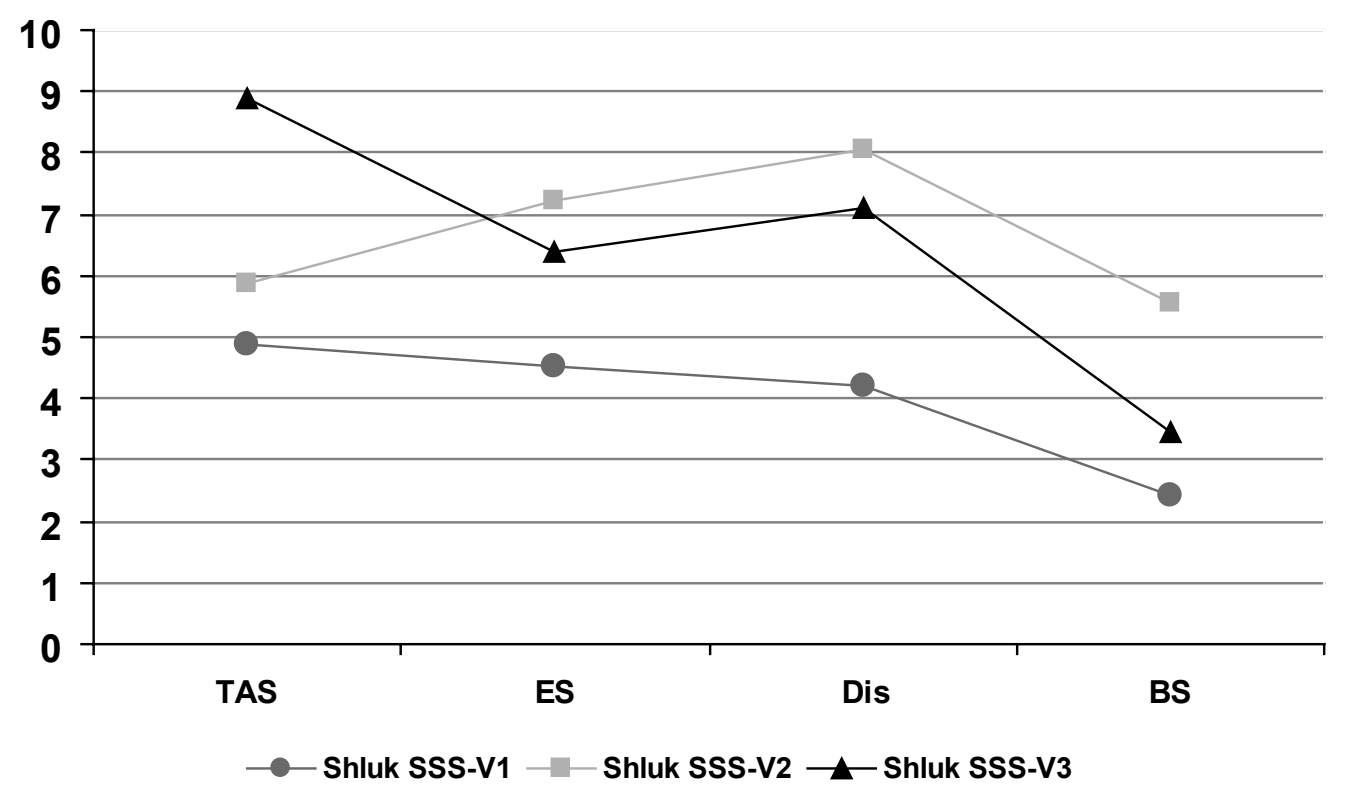

Obrázek 1. Zobrazení shluků pro část dotazníku SSS-V.

Pozn.: TAS - vyhledávání napětí a dobrodružství, ES - vyhledávání zkušeností (oblast smyslového vnímání), Dis - disinhibice (míra respektování morální, právních a sociálních norem), BS vnímavost nudy. Vertikální osa grafu znázorňuje průměrný skór u sledovaných subškál (TAS, ES, Dis, BS). 
Graf na obrázku 1 a tabulka 1 zobrazují a popisují tři vygenerované shluky části dotazníku SSS-V, kde shluk 1 (středně šedá barva) obsahuje 109 respondentů, shluk 2 (světle šedá barva) 79 a shluk 3 (černá barva) 112. Při analýze hodnotíme rozložení respondentů z hlediska př́islušnosti ke sportovně či všeobecně zaměřené tř́ídě a $\mathrm{z}$ hlediska pohlaví.

Tabulka 1

Popisné charakteristiky shluků SSS-V

\begin{tabular}{lccccccc}
\hline & \multicolumn{2}{c}{ Shluk SSS-V1, $\mathrm{n}=109$} & \multicolumn{2}{c}{ Shluk SSS-V2, $\mathrm{n}=79$} & \multicolumn{2}{c}{ Shluk SSS-V3, $\mathrm{n}=112$} & Průměr \\
\hline Proměnná & $\mathrm{M}$ & $s$ & $\mathrm{M}$ & $s$ & $\mathrm{M}$ & $s$ & $\mathrm{M}$ \\
\hline TAS & 4,87 & 2,13 & 5,86 & 1,81 & 8,90 & 1,01 & 6,64 \\
ES & 4,54 & 1,65 & 7,23 & 1,38 & 6,37 & 1,86 & 5,93 \\
Dis & 4,19 & 1,96 & 8,05 & 1,61 & 7,10 & 1,88 & 6,29 \\
BS & 2,41 & 1,60 & 5,56 & 1,58 & 3,46 & 1,47 & 3,63 \\
\hline
\end{tabular}

Pozn.: TAS - vyhledávání napětí a dobrodružství, ES - vyhledávání zkušeností (oblast smyslového vnímání), Dis - disinhibice (míra respektování morální, právních a sociálních norem), BS vnímavost nudy. M je průměr, s je směrodatná odchylka.

Shluk SSS-V1 (středně šedý) má ve všech čtyřech subškálách TAS, ES, Dis a BS nejnižší hodnoty a je druhý nejpočetnější - je v něm 109 respondentů tedy 36,3 \%. Tito studenti mají nízkou tendenci vyhledávat napětí a dobrodružství, nejméně ze všech studentů vyhledávají nové smyslové zkušenosti, nejvíce respektují sociální a morální normy a jsou nejvíce rezistentní vůči nudě. Skupina je pracovně nazvána jako Umírnění. Z hlediska příslušnosti ke sportovně či všeobecně zaměřené třídě a z hlediska pohlaví je v tomto shluku $43,9 \%$ všech dívek, $44,8 \%$ všech dívek všeobecně zaměřených tříd a pouze $27,9 \%$ všech chlapců všeobecných tříd.

Shluk SSS-V2 (světle šedý) má podprůměrné TAS, má vysoké neboli nadprůměrné ES, stejně tak Dis i BS. Do této skupiny patř́i 79 studentů, tedy 26 \%. Tito studenti podprůměrně vyhledávají napětí a dobrodružství, nadprůměrně vyhledávají nové smyslové zkušenosti a prožitky prostřednictvím nerespektování sociálních a morálních norem a jsou nejméně rezistentní vůči opakujícím se podnětům a vůči nudě ze všech tří shluků. Tyto respondenty pracovně nazývám Experimentátoři. Z hlediska příslušnosti ke sportovně či všeobecně zaměřené třídě a $\mathrm{z}$ hlediska pohlaví je ze všech studentů sportovních tříd v tomto shluku zastoupeno pouze $23,4 \%$ z nich. Je zde $21 \%$ všech 
dívek a pouze 13,9\% dívek sportovních tříd. Do tohoto shluku tedy nejčastěji patři chlapci z obou typů tříd a následně dívky všeobecných tříd. Nejméně často zde jsou dívky sportovních tříd.

Shluk SSS-V3 (černý) je charakteristický vysokým TAS, mírně nadprůměrnými ES a Dis a mírně podprůměrným BS. V tomto shluku je nejvíc studentů ze všech shluků, a to 112 , což je $37,3 \%$. Tito studenti velmi výrazně vyhledávají napětí a dobrodružství, mírně nadprůměrně vyhledávají nové především smyslové zkušenosti, stejně tak mírně nadprůměrně nerespektují sociální a morální normy a jsou mírně nadprůměrně rezistentní vůči nudě. Tato skupina je pracovně nazvána Dobrodruzi. Z hlediska př́slušnosti ke sportovně či všeobecně zaměřené třídě je v tomto shluku $41,4 \%$ všech studentů sportovních tříd a z hlediska pohlaví je zde 40,1\% všech chlapců. Dále v tomto shluku je $41 \%$ všech chlapců všeobecných tříd, 43,05 \% všech dívek sportovních tříd a 39,5\% chlapců sportovních tříd. Nejčastěji do tohoto shluku tedy patří dívky sportovních tříd a chlapci všeobecných a následně sportovních tříd.

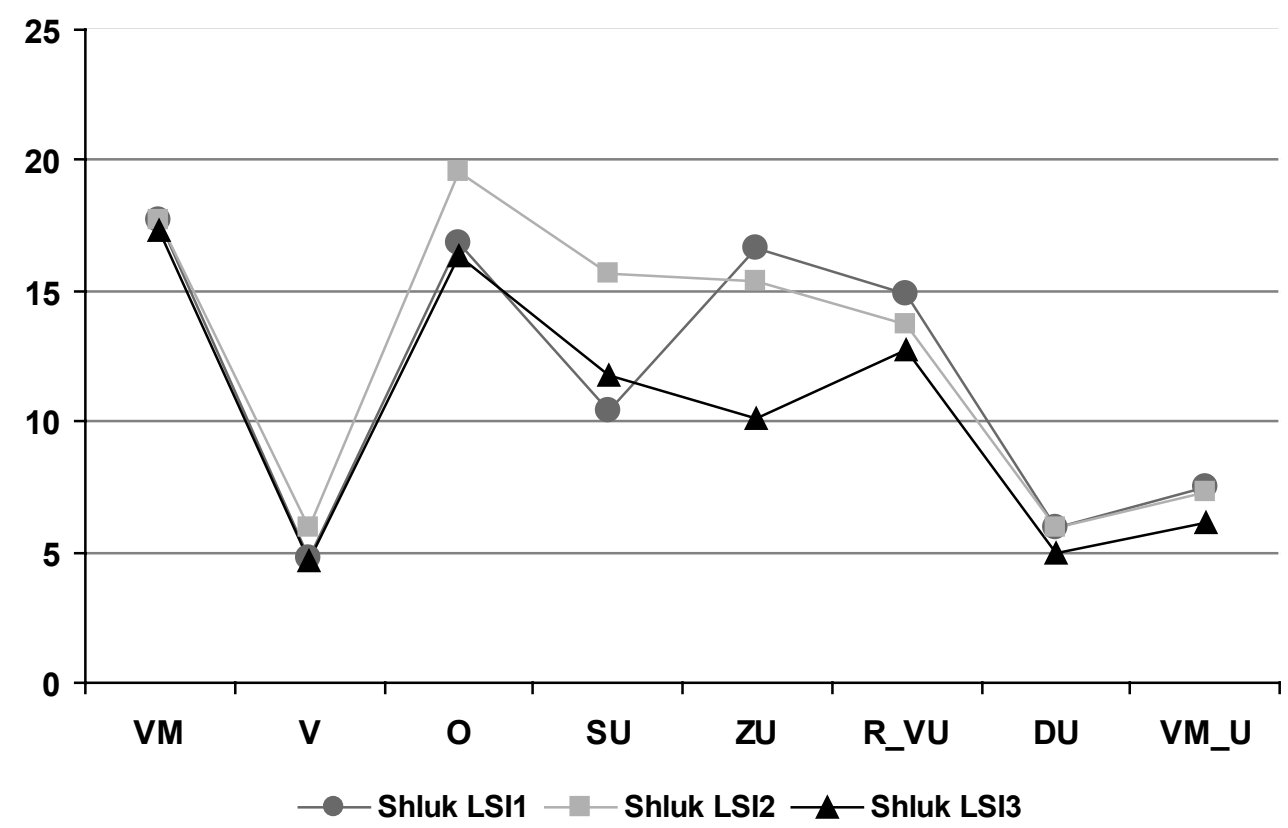

Obrázek 2. Zobrazení shluků pro část dotazníku LSI.

Pozn.: VM - vnitřní motivace, V - vytrvalost při učení, O - odpovědnost při učení, SU strukturování úkolů, ZU - zážitkové učení, R_VU - ranní-večerní učení, DU - dopolední učení, VM_U - vnitřní motivace - učení. Vertikální osa grafu znázorňuje průměrný skór u sledovaných subškál (VM, V, O, SU, ZU, R_VU, DU, VM_U). 
Graf na obrázku 2 a tabulka 2 zobrazují a popisují tři vygenerované shluky části dotazníku LSI, kde shluk 1 (středně šedá) obsahuje 99 respondentů, shluk 2 (světle šedá) 118 a shluk 3 (černá) 83 respondentů. Při analýze opět hodnotím rozložení respondentů z hlediska př́slušnosti ke sportovně či všeobecně zaměřené tř́ídě a $\mathrm{z}$ hlediska pohlaví.

Tabulka 2

Popisné charakteristiky shlukủ LSI

\begin{tabular}{lccccccc}
\hline & \multicolumn{2}{c}{ Shluk LSI1, $\mathrm{n}=99$} & \multicolumn{2}{c}{ Shluk LSI2, $\mathrm{n}=118$} & \multicolumn{2}{c}{ Shluk LSI3, $\mathrm{n}=83$} & Průměr \\
\hline Proměnná & $\mathrm{M}$ & $s$ & $\mathrm{M}$ & $s$ & $\mathrm{M}$ & $s$ & $\mathrm{M}$ \\
\hline VM & 17,69 & 1,75 & 17,96 & 1,78 & 17,31 & 2,19 & 17,65 \\
V & 4,80 & 1,69 & 5,91 & 1,86 & 4,65 & 1,82 & 5,12 \\
O & 16,84 & 2,95 & 19,56 & 2,50 & 16,30 & 2,96 & 17,76 \\
SU & 10,41 & 2,51 & 15,64 & 1,99 & 11,73 & 2,85 & 12,83 \\
ZU & 16,67 & 1,99 & 15,37 & 2,51 & 10,13 & 2,45 & 14,35 \\
R_VU & 14,84 & 3,06 & 13,68 & 2,74 & 12,72 & 2,72 & 13,80 \\
DU & 5,92 & 2,17 & 5,97 & 2,20 & 4,95 & 2,04 & 6,45 \\
VM_U & 7,45 & 1,85 & 7,28 & 1,79 & 6,16 & 1,89 & 7,03 \\
\hline
\end{tabular}

Pozn.: VM - vnitřní motivace, V - vytrvalost při učení, 0 - odpovědnost při učení, SU strukturování úkolů, ZU - zážitkové učení, R_VU - ranní-večerní učení, DU - dopolední učení, VM_U - vnitřní motivace - učení. M je průměr, s je směrodatná odchylka.

Podíváme-li se na graf na obrázku 2 a tabulku 2, lze vidět, že všechny tři shluky jsou v některých proměnných podobných hodnot nebo hodnot spíše s menšími rozdíly. Je tomu tak u proměnné VM (vnitřní motivace), $\mathrm{V}$ (vytrvalost při učení), DU (dopolední učení) a VM_U (vnitřní motivace - učitel). 0 něco větší rozdíly jsou u proměnné $\mathrm{O}$ (odpovědnost) a RV_U (ranní-večerní učení) a výrazné rozdíly jsou v proměnných SU (potřeba strukturovaných úkolů) a ZU (zážitkové učení).

Ve shluku LSI1 jsou nejvíce zastoupeni studenti s mírně nadprůměrnou odpovědností při učení, mají ze všech tř́i shluků nejnižší potřebu strukturovaných úkolů, naopak mají nejvyšší a celkově výrazně nadprůměrnou potřebu se učit zážitkově. $V$ tomto shluku je 99 respondentů, tedy $33 \%$. Tito studenti z hlediska preferencí ranního či večerního učení nejvíce ze všech shluků preferují ranní učení a nejméně učení se večer. Tato skupina byla označena jako Samostatní prožitkáři. Patří sem 38,9\% všech dívek sportovně zaměřených 
tříd. Nejméně zde je chlapců ze sportovních tříd, a to 29,1\%. Ostatní skupiny jsou rozloženy velmi podobně.

Shluk LSI2 je charakteristický nízkou odpovědností při učení, vysokou potřebou strukturovaných úkolů, nadprůměrnou preferencí zážitkového učení a průměrným učením se ráno vs. večer, tedy výrazně nepreferují ani ranní ani večerní učení. Do tohoto shluku se řadí 118 studentů, což je 39,3 \%, tedy jde o nejpočetnější shluk. Je zde $41,1 \%$ všech studentů sportovně zaměřených tříd a 42,2 \% všech chlapců. Při diferenciaci dle pohlaví je zastoupeno 45,3 \% všech chlapců sportovních tříd. Při hledání „typického“ respondenta z tohoto shluku můžeme říct, že jím nejčastěji je student sportovně zaměřené třídy a častěji jde o chlapce. Tato skupina je pracovně nazvána jako Méně zodpovědní nekreativní prožitkáři.

Shluk LSI3 má podobně nadprůměrnou míru odpovědnosti při učení se shlukem LSI1, stejně tak má mírně podprůměrnou potřebu strukturovaných úkolů a je typický výrazně podprůměrnou preferencí zážitkového učení. Nejméně je zde preferováno ranní učení i dopolední učení. Nejnižší hodnoty má tento shluk i v oblasti motivace učitelem. Do této skupiny patří 83 studentů, což je $27,7 \%$, tedy jde o nejméně početný shluk. Tato skupina je pracovně nazvána jako Neprožitkové sovy a je zde nízké zastoupení studentů sportovně zaměřených tříd, a to 25,3\% a nízké zastoupení chlapců, kterých je $26,5 \%$ $\mathrm{z}$ celkového počtu. Do tohoto shluku tedy nejčastěji spadají dívky ze všeobecných tříd a následně chlapci ze všeobecných tříd.

Jelikož je zohledňováno velké množství proměnných a skupin, pro přehlednost jsou uvedeny tabulky 3 a 4 . Z tabulek je patrné, že nejrovnoměrněji jsou studenti zastoupeni ve shlucích LSI1 (Samostatní prožitkáři) a LSI3 (Neprožitkové kreativní sovy) a naopak nejdiferencovanější je zastoupení ve shlucích SSS-V1 (Umírnění), SSS-V3 (Dobrodruzi) a SSS-V2 (Experimentátoři). Potvrzuje se náznak ze základních popisných charakteristik, že rozdíly mezi studenty z pohledu příslušnosti ke sportovní či všeobecné tř́idě a z hlediska pohlaví jsou patrnější v oblasti vyhledávání prožitků než v oblasti preferovaných učebních stylů. Jinak řečeno studenti gymnázií ve všeobecných i sportovních třídách, chlapci i dívky preferují podobné styly učení. Zároveň mají tito studenti do jisté míry různou tendenci vyhledávat prožitky. 
Tabulka 3

Procentuální rozložení sledovaných skupin vzhledem k jejich celkovému počtu v jednotlivých shlucích

\begin{tabular}{lcccc}
\hline Shluk & $\begin{array}{c}\text { Studenti } \\
\text { všeobecných } \\
\text { tř́l }\end{array}$ & $\begin{array}{c}\text { Studenti } \\
\text { sportovních } \\
\text { tř́d }\end{array}$ & Dívky & Chlapci \\
\hline \% studentů & \% studentů & \% studentů & \% studentů \\
\hline SSS-V1 & 37,3 & 35,4 & 43,9 & 28,6 \\
SSS-V2 & 30,0 & 23,4 & 21,0 & 31,1 \\
SSS-V3 & 33,1 & 41,1 & 35,1 & 40,1 \\
LSI1 & 32,4 & 33,5 & 35,8 & 31,3 \\
LSI2 & 37,3 & 41,1 & 35,1 & 42,2 \\
LSI3 & 30,3 & 25,3 & 29 & 26,5 \\
\hline
\end{tabular}

Tabulka 4

Procentuální rozložení sledovaných skupin dle pohlaví vzhledem k jejich celkovému počtu v jednotlivých shlucích

\begin{tabular}{lcccc}
\hline Shluk & $\begin{array}{c}\text { Dívky } \\
\text { všeobecných } \\
\text { tř́́d }\end{array}$ & $\begin{array}{c}\text { Chlapci } \\
\text { všeobecných } \\
\text { tř́d }\end{array}$ & $\begin{array}{c}\text { Dívky } \\
\text { sportovních } \\
\text { tř́́d }\end{array}$ & $\begin{array}{c}\text { Chlapci } \\
\text { sportovních } \\
\text { tř́́d }\end{array}$ \\
\hline \%studentů & \% studentů & \% studentů & \% studentů \\
\hline SSS-V1 & 44,8 & 27,9 & 43,05 & 29,1 \\
SSS-V3 & 27,6 & 31,1 & 13,9 & 31,4 \\
LSI1 & 27,6 & 41,0 & 43,05 & 39,5 \\
LSI2 & 32,9 & 34,4 & 38,9 & 29,1 \\
LSI3 & 34,2 & 37,7 & 36,1 & 45,3 \\
\hline
\end{tabular}

Srovnáme-li rozložení studentů napříč shluky LSI a SSS-V, nacházíme počty společných respondentů obou částí, které naznačují tabulky 5 a 6 . Nejvíce společných respondentů sdílí shluky SSS-V3 a LSI1 a shluky LSI2 a SSS-V2. 41,4\% studentů ze shluku LSI1 je zároveň ve shluku SSS-V3 a 44,3\% studentů ze shluku SSS-V2 je zároveň ve shluku LSI2. 
Tabulka 5

Procentuální zastoupení studentů ze shluků LSI ve shlucích SSS-V z jejich celkového počtu

\begin{tabular}{|c|c|c|c|}
\hline Shluk & $\begin{array}{c}\text { Zastoupení respondentů } \\
\text { ze shluku LSI1 }(n=99) \\
\text { ve shlucích SSS-V }\end{array}$ & $\begin{array}{l}\text { Zastoupení respondentů } \\
\text { ze shluku LSI2 }(\mathrm{n}=118) \\
\text { ve shlucích SSS-V }\end{array}$ & $\begin{array}{c}\text { Zastoupení respondentů } \\
\text { ze shluku LSI3 }(n=83) \\
\text { ve shlucích SSS-V }\end{array}$ \\
\hline $\begin{array}{l}\text { SSS-V1 } \\
n=109\end{array}$ & $38,4 \%$ & $35,6 \%$ & $34,9 \%$ \\
\hline $\begin{array}{l}\text { SSS-V2 } \\
n=79\end{array}$ & $20,2 \%$ & $29,7 \%$ & $28,9 \%$ \\
\hline $\begin{array}{l}\text { SSS-V3 } \\
n=112\end{array}$ & $41,4 \%$ & $34,7 \%$ & $36,2 \%$ \\
\hline
\end{tabular}

Pozn.: Tučně jsou označena nadprůměrná nebo naopak podprůměrná zastoupení respondentů.

Tabulka 6

Procentuální zastoupení studentů ze shluků SSS-V ve shlucích LSI z jejich celkového počtu

\begin{tabular}{lccc}
\hline Shluk & $\begin{array}{c}\text { Zastoupení respondentů } \\
\text { ze shluku SSS-V1 } \\
(\mathrm{n}=109) \text { ve shlucích LSI }\end{array}$ & $\begin{array}{c}\text { Zastoupení respondentů } \\
\text { ze shluku SSS-V2 }(\mathrm{n}=79) \\
\text { ve shlucích LSI }\end{array}$ & $\begin{array}{c}\text { Zastoupení respondentů } \\
\text { ze shluku SSS-V3 } \\
(\mathrm{n}=112) \text { ve shlucích LSI }\end{array}$ \\
\hline $\begin{array}{l}\text { LSI1 } \\
\mathrm{n}=99\end{array}$ & $34,9 \%$ & $\mathbf{2 5 , 3 \%}$ & $36,6 \%$ \\
LSI2 & & & $36,6 \%$ \\
$\mathrm{n}=118$ & $38,5 \%$ & $\mathbf{4 4 , 3 \%}$ & $\mathbf{2 6 , 8 \%}$ \\
LSI3 & & $30,4 \%$ & $\mathbf{2 6} \%$ \\
$\mathrm{n}=83$ & $\mathbf{2 6 , 6 \%}$ & 3 & \\
\hline
\end{tabular}

Pozn. Tučně jsou označena nadprůměrná nebo naopak podprůměrná zastoupení respondentů.

Respondenty, kteří jsou společní pro shluky LSI a SSS-V, lze rozdělit na pět skupin, jejichž pojmenování, společná charakteristika a nejčastější zástupci jsou následující.

Umírnění odpovědní kreativní prožitkáři: Mají vysokou odpovědnost při učení, nízkou tendenci vyhledávat mimořádné prožitky a nízkou potřebu strukturovaných úkolů. Výrazně preferují zážitkové učení a učení v ranních hodinách. Nejčastěji jde o děvčata. 
Odvážní netrpěliví experimentátoři: Nevyhledávají napětí a dobrodružství, mají nízkou rezistenci vůči nudě a nízký respekt vůči normám a vyšší tendenci hledat nové smyslové zkušenosti. Nejčastěji jde o chlapce a nesportující dívky.

Prožitkově naladění kreativní dobrodruzi: Vyhledávají napětí a dobrodružství a nové zkušenosti, nadprůměrně nerespektují normy, mají podprůměrnou odpovědnost, bez potřeby strukturovatúkoly, preferují zážitkové učenía učení ráno. Převážně jde o studenty sportovních tř́íd bez ohledu na pohlaví.

Rebelující trpěliví méně odpovědní nekreativní prožitkáři: Podprůměrně vyhledávají napětí a dobrodružství, mají nadprůměrný zájem o nové zkušenosti, mají nízký respekt k normám, jsou odolní vůči nudě, jsou neodpovědní, potřebují strukturované úkoly a preferují zážitkové učení. Nejčastěji jde o chlapce.

Rebelující trpěliví méně odpovědní nekreativní experimentátoři: Podprůměrně vyhledávají napětí a dobrodružství a jsou spíš neodpovědní, nadprůměrně hledají nové zkušenosti a nerespektují sociální a morální normy, jsou odolní vůči nudě, při učení jsou kreativní, nepreferují zážitkové učení a jsou nejméně motivováni učitelem. Nejčastěji jde o chlapce obou typů tříd a dívky ze všeobecných tříd.

\section{Diskuze a doporučení do praxe}

Nahlédneme-li nejpodstatnější zjištění z hlediska vyhledávání mimořádných prožitků, lze říci, že děvčata všeobecných tříd mají ze všech skupin nejnižší tendenci vyhledávat mimořádné prožitky a jsou nejvíce tzv. Neprožitkové kreativní sovy. Jsou při učení nadprůměrně odpovědné, mají nízkou potřebu strukturovaných úkolů, nepreferují zážitkové učení, ranní či dopolední učení a jsou málo motivované učitelem. Tato skupina studentek při učení tedy nijak zvlášt' nevyžaduje vzrušení, nové zážitky, smyslové zkušenosti a pohyb, respektuje pravidla a normy a nemá problém s nudou. Na základě manuálu Dotazníku stylu učení (Dunnová, Dunn, \& Price, 1989) lze ve výuce těchto děvčat doporučit rozvíjení individuální i skupinové odpovědnosti, stavět na ní, nechávat studentky volit vlastní učební strategie, postupy, využívat jejich kreativity a $\mathrm{v}$ domácím prostředí poskytnout čas $\mathrm{k}$ učení večer, nikoliv ráno. Naopak chlapci sportovních tříd jsou nejčastěji tzv. Méně odpovědní nekreativní prožitkáři. Mají nízkou odpovědnost při učení, mají potřebu strukturovaných úkolů a preferují zážitkové učení. Tedy s touto skupinou je vhodné 
postupně posilovat a rozvíjet jejich individuální i skupinovou odpovědnost a samostatnost při učení - $v$ jednodušších úkolech delegovat zodpovědnost za výběr, za postup či např. za časové rozvržení. Vhodné je do učení zapojit pohyb, prožitek, herní program či např. přímou zkušenost z "reálného“ světa. Dívky sportovních tříd patří mezi tzv. Umírněné, ale stejně tak často také mezi tzv. Dobrodruhy. Tedy tyto dívky se svými požadavky na výuku $\mathrm{z}$ pohledu tendence vyhledávat mimořádné prožitky podobají jak dívkám všeobecných tř́d, tak chlapcům obecně. V oblasti učebních stylů a z hlediska pohlaví a př́slušnosti $\mathrm{k}$ typu třídy jsou dívky sportovních tříd nejčastěji tzv. Samostatné prožitkářky. Jsou při učení nadprůměrně odpovědné, preferují zážitkové učení a učení ráno. Tedy také, jako u chlapců, je vhodné těmto studentkám nabízet pohybovou, prožitkovou a zkušenostní výuku, stavět na jejich odpovědnosti a tu dále posilovat a nejnáročnější úkoly zařazovat v ranních hodinách. Chlapci všeobecných tříd častěji nespadají do žádné konkrétní skupiny, preferují všechny sledované učební styly rovnoměrně.

Hovoříme-li o rozdílech mezi pohlavími bez ohledu na př́slušnost $\mathrm{k}$ typu tř́ídy, ze studie vyplývá, že z hlediska vyhledávání mimořádných prožitků jsou chlapci gymnaziálních tříd nejčastěji tzv. Dobrodruzi. Ty charakterizuje vyhledávání napětí a dobrodružství a smyslových zkušeností, menší respekt k normám a nedobrá snášenlivost vưči nudě. Tedy předpoklad, který publikuje Ang a Woo (2003), že chlapci s vysokou tendencí vyhledávat mimořádné prožitky mají negativnější přístup ke školní docházce a více inklinují $\mathrm{k}$ hyperaktivitě a kriminalitě než chlapci s nízkou tendencí, je pravděpodobnější u chlapců než u děvčat (o kterých Ang a Woo nehovoří). Podobně Carter a Stewin (1999) indikují vazbu mezi vyhledáváním mimořádných prožitků, nedostatečnými studijními dovednostmi, asociálním a nekonformním chováním a obecnou nespokojeností s učiteli a školou. I v tomto případě je dle této studie uvedený projev pravděpodobnější u chlapců. Neméně důležité je upozornění Farleyho (1981), že nepodnětné vzdělávací metody tlumí intelektuální zvídavost těch žáků a studentů, jejichž tendence vyhledávat mimořádné prožitky je nadprůměrná. I v tomto případě jde častěji o chlapce.

Možnou cestou, jak tuto větší míru prožitkovosti respektovat, je hledat vhodné výukové metody a postupy, které naopak přispějí k saturaci žákovy potřeby vyhledávat prožitky. Studie se shodují, že pozitivní intelektuální výsledky jsou závislé na správném vyučování (Wentzel, 1993) a že je vhodné aplikovat kompatibilní výukové metody k preferovaným učebním stylům (Lovelace, 2005). Tedy jinak řečeno, že je vhodné zohledňovat potřeby konkrétních žáků 
včetně jejich míry vyhledávat mimořádné prožitky. Pro zohlednění žákova preferovaného učebního stylu je nejprve třeba učební styl diagnostikovat. Diagnostikování učebních stylů může být př́nosné jak pro žáka, tak pro učitele a v důsledku pro celý edukační proces. Je-li k tomuto kroku přistoupeno, učitel se po fázi diagnostikování rozhoduje, bude-li učební styly žáků ovlivňovat, bude-li je ovlivňovat pouze částečně nebo nebude-li je ovlivňovat vủbec a bude je pouze respektovat. Všechny tři př́istupy mají své přednosti i limity, které blíže popisuje Mareš (2013, s. 209).

\section{Závěry}

Cílem studie bylo zjistit, jaké učební styly studenti preferují v souvislosti s různou mírou tendence vyhledávat mimořádné prožitky, respektive jaké tvoří z hlediska subškál těchto dvou proměnných přirozené skupiny (shluky). Cílem také bylo přispět do diskuze o kompatibilitě učebních stylů a vyučovacích metod i o vztahu míry tendence vyhledávat mimořádné prožitky a učebního procesu.

Nejpodstatnější zjištění jsou ta, že nejvyšší tendenci vyhledávat mimořádné prožitky mají mezi sledovanými gymnaziálními studenty chlapci bez ohledu na příslušnost $\mathrm{k}$ typu třídy, druhými nejvíce vyhledávajícími mimořádné prožitky jsou dívky sportovních tříd. Zároveň studenti $\mathrm{s}$ nadprůměrnou tendencí vyhledávat mimořádné prožitky neupřednostňují stejný učební styl či styly. Nejnižší tendenci vyhledávat mimořádné prožitky mají nesportující děvčata ze všeobecných tříd a ani studenti s nízkou tendencí vyhledávat mimořádné prožitky neupřednostňují stejný učební styl.

Ve shlukové analýze nejsou ve většině případů rozdíly mezi zastoupením jednotlivých skupin studentů do shluků velmi vysoké. Výjimku tvoří shluk SSSV1 (Umírnění), kde zastoupení dívek výrazně převyšuje zastoupení chlapců, shluk SSS-V2 (Experimentátoři), kde je výrazně nízký počet dívek sportovních tříd a shluk LSI2 (Méně odpovědní nekreativní prožitkáři), kde je výrazně vyšší počet chlapců ze sportovních tříd. Umírnění nejméně ze všech vyhledávají napětí a dobrodružství, nevyhledávají nové zkušenosti, jsou nejvíce rezistentní vůči nudě a nejvíce respektuji sociální a morální normy. Experimentátoři jsou převážně chlapci, kteří naopak vyhledávají nové zkušenosti, nepř́liš respektují společenské normy a jsou málo odolní vůči nudě. Experimentátoři nijak zvlášt' nevyhledávají napětí a dobrodružství, ovšem velmi vyhledávají nové, především smyslové zkušenosti, prožitky prostřed- 
nictvím nerespektování sociálních a morálních norem a jsou nejméně rezistentní vůči opakujícím se podnětům a vůči nudě. Méně odpovědní nekreativní prožitkáři jsou nejčastěji chlapci ze sportovně zaměřených tříd a tito chlapci mají nižší odpovědnost při učení, úkoly potřebují mít strukturované a preferují zážitkové učení.

Uvedenými výsledky přispívám do diskuze o učebním stylu studenta a jeho tendenci vyhledávat mimořádné prožitky. Jak uvádí Lovelace (2005, s. 181), je vhodné aplikovat kompatibilní výukové metody k preferovaným učebním stylům žáků, na druhou stranu Mareš (2013, s. 209) popisuje i limity tohoto přístupu. $V$ každém př́ípadě zamyšlení nad souvislostí mezi mírou tendence vyhledávat mimořádné prožitky a preferovaným učebním stylem může být přispěním do nových pohledů na učební proces.

Na závěr je nutné zmínit, že výzkum byl proveden pouze u třetích, respektive sedmých ročníků čtyřletých či osmiletých gymnázií, není tedy možné zjištěné výsledky vztahovat na širší populaci studentů. Rozšíření výzkumu na další ročníky a studijní zaměření může být předmětem dalšího šetření.

\section{Literatura}

Ang, R. P., \& Woo, A. (2003). Influence of sensation seeking on boys' psychological adjustment. North American Journal of Psychology, 5(1), 121-136.

Blum, R. W., Beuhring, T., \& Rinehart, P. M. (2000). Protecting teens: Beyond race, income, and family structure. Minneapolis, MN: University of Minnesota Printing Services.

Breivik, G. (1999). Sensation seeking in sport. Oslo: Norges idretthogskole institutt for samfunnsfag.

Carter, S. P., \& Stewin, L. L. (1999). School violence in the Canadian context: An overview and model for intervention. International Journal for the Advancement of Counseling, 21(4), 267-277.

Dunn, R., \& Dunn, K. (1978). Teaching students through their individual learning styles: A practical approach. Reston: Reston Publishing.

Dunn, R. (2000). Learning styles: Theory, research, and practice. National Forum of Applied Educational Research Journal, 13(1), 3-22.

Dunn, R., Dunn, K., \& Price, G. E. (1989). Learning style inventory. Lawrence: Price System, Inc.

Farley, F. H. (1981). Basic process individual differences: A biological based theory of individualization for cognitive, affective, and creative outcomes. In F. H. Farley \& N. J. Gordon (Eds.), Psychology and education: The state of the union (s. 9-31). Berkeley, CA: McCutchon Publishing Corporation.

Galloway, G., \& Lopez, K. (1999). Sensation seeking and attitudes to aspects of national parks: A preliminary empirical investigation. Tourism Management, 20(6), 665-671. 
Glasgow, M. R., Cartier, A. M., \& Wilson, G. D. (1985). Conservatism, sensation-seeking, and music preferences. Personality and Individual Differences, 6(3), 395-396.

Hošek, V. (1997). Pohyb a kvalita života. Tělesná výchova a sport mládeže, 63(7), 7-9.

Jaffe, L. T., \& Archer, R. P. (1987). The prediction of drug use among college students from MMPI, MMCI, and sensation seeking scale. Journal of Personality Assessment, 51(1), 243-253.

Krásová, P., \& Rost, M. (2008). Tendence vyhledávat mimořádné prožitky u vysokoškoláků ve vztahu k osobnostním charakteristikám. Studia Kinanthropologica, 2(9), 238-245.

Kuban, J. (2001). Komparace Sensation Seeking Tendency u hráčů sportovních her. In L. Čepička (Ed.), Hry v programech tělovýchovných procesů (s. 41-46). Plzeň: Západočeská univerzita.

Kuban, J. (2006). Tendence $k$ vyhledávání prožitku a její diagnostika. Hradec Králové: Gaudeamus.

Lovelace, M. (2005). Meta-analysis of experiential research based on the Dunn and Dunn model. The Journal of Educational Research, 98(3), 176-183.

Mareš, J. (1998). Styly učení žáků a studentů. Praha: Portál.

Mareš, J. (2013). Pedagogická psychologie. Praha: Portál.

Mareš, J., \& Slavík, V. (2004). Dotazník stylu učení. Praha: IPPP ČR.

Mareš, J., \& Skalská, H. (1994). LSI - dotaznik stylů učeni pro žaky zakladnich a střednich škol. Psychológia a patopsychológia diet’ata, 29(3), 248-264.

Montag, I., \& Birenbaum, M. (1986). On the location of the sensation seeking construct in the personality domain. Multivariate Behavioral Research, 21(3), 357-374.

Rybenský, D. (2008). Konstrukce standardů pro test prožitkovosti - Sensation Seeking Tendency (česká verze) (Diplomová práce). Hradec Králové: PdF UHK.

Watson, C. G., \& Jacobs, L. (1977). Evidence for a dual-factor concept of psychopathological emotional deficit: Anhedonia and sensation-seeking. Jounal of Clinical Psychology, 33(2), 385-389.

Wentzel, K. R. (1993). Social and academic goals at school: Motivation and achievement in early adolescence. Journal of Early Adolescence, 13(1), 4-20.

Zuckerman, M. (1978). Sensation seeking. In H. London \& J. Exner (Eds.), Dimensions of personality (s. 487-555). New York: Wiley.

Zuckerman, M. (1979). Sensation seeking: Beyond the optimal level of arousal. Hillsdale: Erlbaum.

Zuckerman, M. (1994). Behavioral expressions and biosocial bases of sensation seeking. Cambridge: Cambridge University Press.

Zuckerman, M. (2000). Are you a risk taker? Psychology Today, 33(6), 52.

Zuckerman, M. (2009). Sensation seeking. In M. R. Leary \& R. H. Hoyle (Eds.), Handbook of individual differences in social behavior (s. 455-465). New York: Gulford Press.

\section{Autorka}

Mgr. Dita Culková, Univerzita Hradec Králové, Pedagogická fakulta, Katedra tělesné výchovy a sportu, Rokitanského 62, 50003 Hradec Králové, e-mail: dita.culkova@uhk.cz 


\section{Sensation seeking and student's preferred learning style}

Abstract: The objective of this empirical study is to determine what learning style students and how this relates to their sensation seeking tendency. We were also interested in what natural clusters occur if these two variables are considered, together with gender and students' affiliation with general or physical education oriented class at grammar school. Theoretical basis, which are Dunn's theory of learning styles and theory of Zuckerman's sensation seeking tendency, are introduced in the first part. The second part describes used methods including reliability and validity verification of the applied questionnaire. Cluster analysis is the method for data processing and provides a deep insight into a big amount of variables. The third part informs about the main results, discusses them and provides praxis recommendations. The greatest differences between genders and class type were found in sensation seeking tendency, partly in learning styles. Girls of physical education and sport specialized classes least represent cluster, where there is a very little thrill and adventure seeking and seeking of new experiences, where boredom susceptibility is low and respect towards rules and norms is high. Boys are most often members of a cluster where thrill and adventure is not searched but new experiences are welcome, enjoyment follows from disrespect for norms and standards and the members are susceptible to boredom. Boys of physical education and sport classes are little responsible within the learning process, they need structured tasks and they prefer experiential or kinesthetic education. It is possible to state, that the preference of learning style of grammar school students might relate to sensation seeking tendency as well as to gender and type of school class.

Keywords: learning style, cognitive style, sensation, sensation seeking tendency, Learning style, interests and hobby inventory, grammar school with physical education and sports specialization

Dvořák, D. (2012). Od osnov ke standardům. Proměny kurikulární teorie a praxe. Praha: PedF UK.

At’ už si myslíme o nedávné české kurikulární reformě cokoli, nelze jí upř́ít jednu zásluhu. Zpochybnila některé tradiční jistoty v této oblasti, otevřela cestu uvažování o alternativách a celkově probudila nový zájem o problematiku vzdělávacího obsahu. Tato monografie chce do obnovené debaty přispět mimo jiné tím, že vedle obsahových aspektů zkoumá i význam formální podoby či struktury kurikulárních dokumentů. Těžištěm práce je popis vývoje kurikulární teorie a praxe od hnutí za reformu kurikula v šedesátých letech 20 . století do současnosti, především v anglicky mluvících zemích. Druhá část knihy podává přehled metod, jimiž lze projektovou podobu kurikula studovat, a ukazuje jejich aplikace na české vzdělávací programy vzniklé v posledních letech. Publikace je určena všem, kdo mají hlubší zájem o problematiku školního vzdělávání a o vzdělávací reformy. 